\title{
L-arginine, a nitric oxide precursor, reduces dapsone-induced methemoglobinemia in rats
}

\author{
Natália Valadares de Moraes, Mateus Machado Bergamaschi, Maria de Lourdes Pires Bianchi, \\ Juliana Bordinassi Bragheto, Wilson Roberto Malfará, Regina Helena Costa Queiroz
}

\author{
Department of Clinical, Toxicological and Food Sciences Analysis, School of Pharmaceutical Sciences of Ribeirão Preto, \\ University of São Paulo
}

\begin{abstract}
Dapsone use is frequently associated to hematological side effects such as methemoglobinemia and hemolytic anemia, which are related to N-hydroxylation mediated by the P450 enzyme system. The aim of the present study was to evaluate the influence of L-arginine supplementation, a precursor for the synthesis of nitric oxide, as single or multiple dose regimens on dapsone-induced methemoglobinemia. Male Wistar rats were treated with L-arginine at 5, 15, 30, 60 and $180 \mathrm{mg} / \mathrm{kg}$ doses (p.o., gavage) in single or multiple dose regimens 2 hours prior to dapsone administration ( $40 \mathrm{mg} / \mathrm{kg}$, i.p.). The effect of the nitric oxide synthase inhibitor L-NAME was investigated by treatment with multiple doses of 30 $\mathrm{mg} / \mathrm{kg}$ (p.o., gavage) 2 hours before dapsone administration. Blood samples were collected 2 hours after dapsone administration. Erythrocytic methemoglobin levels were assayed by spectrophotometry. The results showed that multiple dose supplementations with 5 and $15 \mathrm{mg} / \mathrm{kg}$ L-arginine reduced dapsoneinduced methemoglobin levels. This effect is mediated by nitric oxide formation, since the reduction in methemoglobin levels by L-arginine is blocked by simultaneous administration with L-NAME, a nitric oxide synthase inhibitor.
\end{abstract}

Uniterms: Dapsone. Methemoglobinemia. L-arginine. Nitric oxide. L-NAME.

\begin{abstract}
O uso da dapsona é frequentemente associado a efeitos adversos hematológicos, como a metemoglobinemia e anemia hemolítica, ambos relacionados com a $N$-hidroxilação mediada pelo sistema P450. O objetivo do estudo foi avaliar a influência da suplementação de L-arginina, um precursor da síntese de óxido nítrico, administrado em regime de dose única ou múltipla na metemoglobinemia induzida pela dapsona. Ratos machos Wistar foram tratados com L-arginina (po, gavagem) em dose única ou múltipla de 5, 15, 30, 60 e $180 \mathrm{mg} / \mathrm{kg} 2$ horas antes da administração de dapsona (40 mg/kg, ip). O efeito do L-NAME, um inibidor de óxido nítrico sintase (NOS), foi avaliado através do tratamento com doses múltiplas de $30 \mathrm{mg} / \mathrm{kg}$. Amostras de sangue foram coletadas duas horas após a administração de dapsona. A concentração de metemoglobina eritrocitária foi analisada por espectrofotometria. Os resultados mostraram que a suplementação em dose múltipla de 5 e $15 \mathrm{mg} / \mathrm{kg}$ de L-arginina reduziu os níveis de metemoglobina induzida pela dapsona. Este efeito é mediado pela formação de óxido nítrico, uma vez que a redução nos níveis de metemoglobina pela L-arginina é bloqueada pela administração simultânea de L-NAME, um inibidor da óxido nítrico sintase.
\end{abstract}

Unitermos: Dapsona. Metemoglobinemia. L-arginina. Óxido nítrico. L-NAME.

\section{INTRODUCTION}

Dapsone $(4,4$ '-diaminodiphenylsulfone, DDS) is

\footnotetext{
*Correspondence: R. H. C. Queiroz. Departamento de Análises Clínicas, Toxicológicas e Bromatológicas, Faculdade de Ciências Farmacêuticas de Ribeirão Preto - USP. Av. do Café, s/n, 14040-903 - Ribeirão Preto - SP, Brazil. E-mail: rqueiroz@fcfrp.usp.br.
}

a potent antibacterial and anti-inflammatory compound and has been clinically used in the treatment of leprosy as a component of a multidrug therapy that includes a combination of DDS, clofazimine and rifampicin (Katoch 2002; Walker, Lockwood 2007). The drug is also used for the treatment of malaria and Pneumocystic carinii pneumonia in patients with acquired immunodeficiency 
syndrome (Powell et al., 1967; Mills et al., 1988; Castro 1998; Tobin-D’Angelo et al., 2004; Nyunt, Plowe 2007).

The major metabolic pathway of DDS is acetylation, producing monoacetyldapsone (MADDS). DDS is also metabolized by $N$-hydroxylation mediated by cytochrome P450 isozymes CYP2C19, CYP2C9, CYP3A4 and CYP2E1 in man, and isozymes CYP2C6/11 and CYP3A1 in rats, producing DDS hydroxylamine (DDS-NOH) (Fleming et al., 1992; Vage, Svensson, 1994; Mitra et al., 1995; Gill et al., 1995; Ganesan et al., 2010). Glucuronidation of DDS and DDS-NOH is catalyzed by the enzyme UDPglucuronosyltransferase (UGT) allowing its excretion in urine and bile (Coleman et al., 1996; Tingle et al., 1997).

The co-oxidation of DDS-NOH and hemoglobin produces nitroso derivatives and methemoglobin, thus causing methemoglobinemia and hemolysis (Tingle et al., 1990; Coleman, 1995), which are the major dosedependent side effects of DDS chronic users (Kaluarachchi et al., 2001). MADDS-NOH has been shown to be a more potent methemoglobin (metHb) former than DDS-NOH in human erythrocytes in vitro (Coleman, Holden, 2004), whilst both metabolites present the same potency in rats and humans (Vage et al., 1994).

The reduction of xenobiotic-induced metHb formation and the mechanisms underlying this effect have been widely investigated in the last few years. The various attempts to reduce methemoglobinemia have included: preventing CYP-mediated oxidative metabolism of xenobiotics to hydroxylamines (Coleman et al., 1990; Malfará et al., 2002); biochemical attenuation of metHb formation with antioxidants (Prussick et al., 1992; Wright et al., 1996; Dötsch et al., 1998; Wright et al., 1998; Dötsch et al., 2000; Tanen et al., 2000; Matteuci et al., 2003; De Moraes et al., 2008; Jo et al., 2008); and reduction of metHb to hemoglobin by stimulating NADH diaphorase or NADPH diaphorase (Dötsch et al., 2000).

L-arginine (ARG), a semi-essential amino acid, is the nitrogenous precursor for the synthesis of nitric oxide (NO) by a NADPH-dependent NO synthase (NOS) and regulates vital metabolic pathways. NO is sufficiently nonpolar to cross membranes without a carrier and is known to modulate vasorelaxation and exhibit antioxidant properties due to superoxide scavenger and heme oxygenase inductor activities (Wood et al., 2008).

In spite of all the evidence pointing to the importance of ARG in vital pathways, the role of ARG supplementation in DDS-induced methemoglobinemia has yet to be described in the literature. The aim of the present study was to evaluate the role of ARG in single and multiple dose regimens in DDS-induced methemoglobinemia. We also evaluated whether the effect of ARG on DDS-induced methemoglobinemia can be modulated by pretreatment with $N$-nitro-L-arginine methyl ester (L-NAME), a nonspecific NOS inhibitor.

\section{MATERIAL AND METHODS}

Dapsone was supplied by FURP (Fundação para o Remédio Popular; Guarulhos, Brazil) and L-(+)-arginine was supplied by Acros organics (Morris Plains, NJ, USA). L-NAME was purchased from Sigma-Aldrich (St. Louis, MO, USA). KCN was supplied by Merck (Darmstadt, Germany) and $\mathrm{K}_{3} \mathrm{Fe}(\mathrm{CN})_{6}$ was supplied by Merck (Rio de Janeiro, Brazil). Water was purified with the Milli-Q Plus system (Millipore, Bedford, MA, USA).

\section{Experimental study}

The experimental study was approved by the Ethics Committee for the Use of Animals of Ribeirão Preto Campus, University of São Paulo, Brazil, in accordance with the US National Institutes of Health Guide for the Care and Use of Laboratory Animals (Protocol number 06.1.461.53.6). Male Wistar rats $(200 \pm 20 \mathrm{~g})$ were kept for 48 hours before the experiment in a room under controlled temperature $\left(21-23^{\circ} \mathrm{C}\right)$ and humidity $(40-60 \%)$ and on a $12 \mathrm{~h}$ light: $12 \mathrm{~h}$ dark cycle. The animals had free access to chow and water throughout the experiment. The animals ( $\mathrm{n}=8$ per group) were treated in single or multiple dose regimens. ARG was administered orally (p.o. gavage, $200 \mu \mathrm{L}$ ), dissolved in sterile physiologic saline, whereas DDS was dissolved in dimethylsulphoxide (DMSO) and administered intraperitoneally (i.p., $200 \mu \mathrm{L}$ ). L-NAME at $30 \mathrm{mg} / \mathrm{kg}$ was administered using a multiple dose regimen in the same solution as ARG.

\section{Single dose regimen}

The control group received the vehicle of ARG (sterile physiological saline) p.o. by gavage two hours before the administration of the vehicle used to dissolve DDS (DMSO) i.p. The DDS group received $40 \mathrm{mg} / \mathrm{kg}$ DDS (i.p.) 2 hours after the administration of saline p.o. The groups DDS $+5 \mathrm{mg} / \mathrm{kg} \mathrm{ARG}, \mathrm{DDS}+15 \mathrm{mg} / \mathrm{kg}$ ARG, DDS + $30 \mathrm{mg} / \mathrm{kg}$ ARG, DDS + $60 \mathrm{mg} / \mathrm{kg}$ ARG, $\mathrm{DDS}+180 \mathrm{mg} / \mathrm{kg}$ ARG received ARG at 5, 15, 30, 60 and $180 \mathrm{mg} / \mathrm{kg}$ doses, respectively, 2 hours before the administration of $40 \mathrm{mg} / \mathrm{kg}$ DDS.

\section{Multiple dose regimen}

The control group received saline for five days p.o. (gavage). On the fifth day, the animals received DMSO i.p. 2 hours after saline administration. The DDS group 
received saline for five days p.o. and $40 \mathrm{mg} / \mathrm{kg}$ DDS on the fifth day, 2 hours after saline administration. Groups $\mathrm{DDS}+5 \mathrm{mg} / \mathrm{kg}$ ARG, DDS + $15 \mathrm{mg} / \mathrm{kg}$ ARG, DDS + 30 $\mathrm{mg} / \mathrm{kg}$ ARG, DDS + $60 \mathrm{mg} / \mathrm{kg}$ ARG, DDS + $180 \mathrm{mg} / \mathrm{kg}$ ARG received ARG at 5, 15,30,60 and $180 \mathrm{mg} / \mathrm{kg}$ doses, respectively, for five days. On the fifth day, 2 hours after ARG administration, the animals received $40 \mathrm{mg} / \mathrm{kg}$ DDS.

Heparinized blood samples were collected two hours after DDS or DMSO administration, in both dose regimens (Liquemine $5000 \mathrm{IU}$, Roche, Rio de Janeiro, Brazil). Methemoglobin levels were determined immediately.

\section{Methemoglobin assay}

Methemoglobin levels relative to hemoglobin levels were determined according to the method described by Evelyn and Malloy (1938) (modified by Harrison and Jollow, 1986). Briefly, an aliquot $(200 \mu \mathrm{L})$ of heparinized blood was added to $10 \mathrm{~mL}$ of $0.02 \mathrm{M}$ phosphate buffer $\mathrm{pH}$ 7.8 with $0.05 \%$ triton $\mathrm{X}-100$ and then shaken in a mixer for 30 seconds. The hemolysate was then fractionated into four tubes. Tube $1\left(\mathrm{~A}_{1}\right)$ remained with hemolyzed blood. An aliquot $(50 \mu \mathrm{L})$ of $20 \% \mathrm{~K}_{3} \mathrm{Fe}(\mathrm{CN})_{6}$ was added to tubes $3\left(\mathrm{~A}_{3}\right)$ and $4\left(\mathrm{~A}_{4}\right)$. An aliquot $(50 \mu \mathrm{L})$ of $10 \% \mathrm{KCN}$ was then added to tubes $2\left(\mathrm{~A}_{2}\right)$ and 4 . The absorbance of each tube was measured at $635 \mathrm{~nm}$. Methemoglobin levels relative to hemoglobin levels were then calculated by the following equation:

$$
\% \text { Methemoglobin }=\left(\frac{A_{1}-A_{2}}{A_{3}-A_{4}}\right) \times 100
$$

The initial blood measurement $\left(A_{1}\right)$ is referent to $\mathrm{MetHb}$ and possible interferences. When blood is added to $\mathrm{KCN}\left(\mathrm{A}_{2}\right)$, MetHb is converted to cyanomethemoglobin $(\mathrm{CNMetHb})$ and then possible interferences are eliminated because $\mathrm{CNMetHb}$ does not absorb at 635 $\mathrm{nm}$. When blood is added to $\mathrm{K}_{3} \mathrm{Fe}(\mathrm{CN})_{6}$ all hemoglobin is converted to $\mathrm{MetHb}$, and this measurement refers to total $\operatorname{MetHb}\left(\mathrm{A}_{3}\right)$. Finally, blood is added to $\mathrm{K}_{3} \mathrm{Fe}(\mathrm{CN})_{6}$ and $\mathrm{KCN}$, with all hemoglobin converted to MetHb and then to $\mathrm{CNMetHb}\left(\mathrm{A}_{4}\right)$.

\section{Statistical analysis}

GraphPad InStat ${ }^{\circledR}$ software (version 3.01) was used for the calculation of means \pm standard deviation. ANOVA and the Tukey-Kramer post test for multiple comparisons $(p<0.05)$ were used to compare groups.

\section{RESULTS}

As there is no reference value for methemoglobin levels in rats, some preliminary studies were conducted in order to evaluate whether ARG or the vehicles could produce methemoglobinemia. A single dose regimen control group was evaluated by administrating sterile physiological saline (p.o., $200 \mu \mathrm{L}$ ) and DMSO (i.p., $200 \mu \mathrm{L}$ ). The administration of these vehicles resulted in $3.77 \pm 0.43 \%$ methemoglobin formation. In a pilot study, rats were treated with 5, 15, 30, 60 and $180 \mathrm{mg} / \mathrm{kg}$ of ARG (p.o., $\mathrm{n}=8$ ) by gavage. Methemoglobin levels were assayed in these groups, resulting in $1.70 \pm 0.09 \%, 1.81 \pm 0.08 \%$,

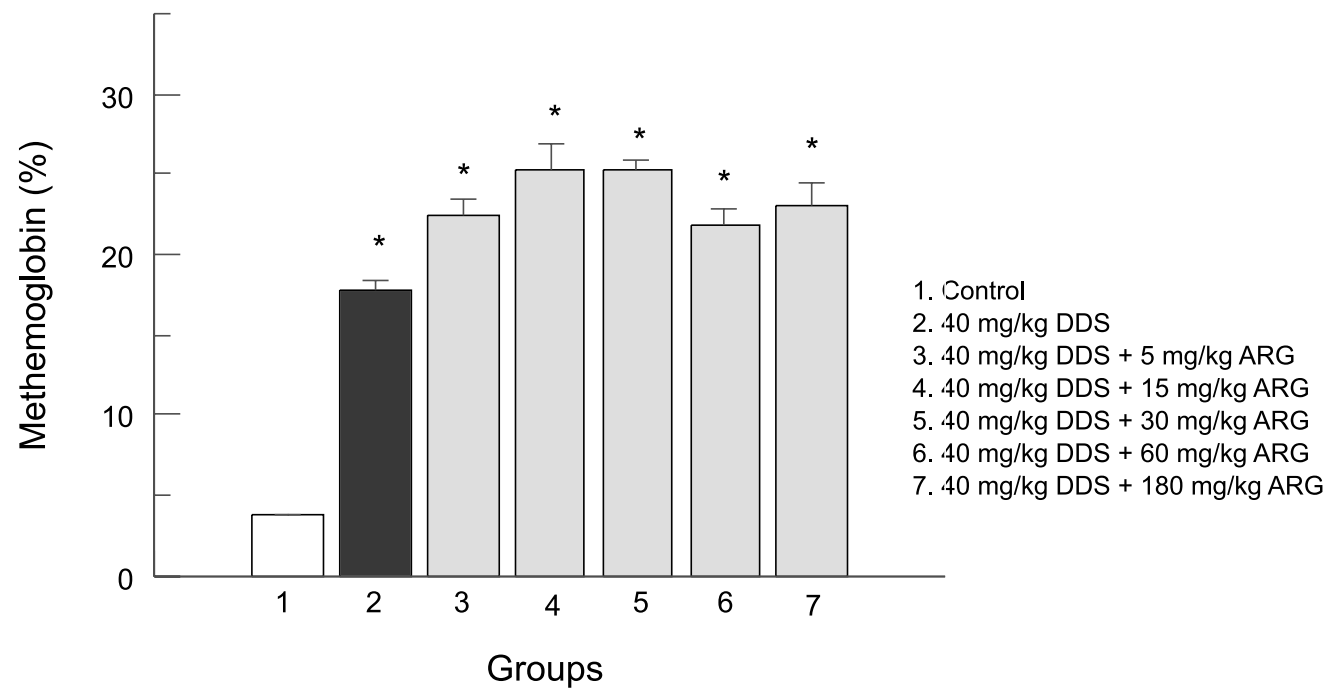

FIGURE 1 - Effect of single dose ARG on methemoglobin levels (\%). Animals were treated with ARG at 5, 15, 30, 60 and $180 \mathrm{mg} / \mathrm{kg}$ doses (p.o., gavage) 2 hours prior to the administration of $40 \mathrm{mg} / \mathrm{kg}$ of DDS (i.p.). Data expressed as means \pm standard deviation. ${ }^{*} \mathrm{p}<0.05$ compared to control group. 


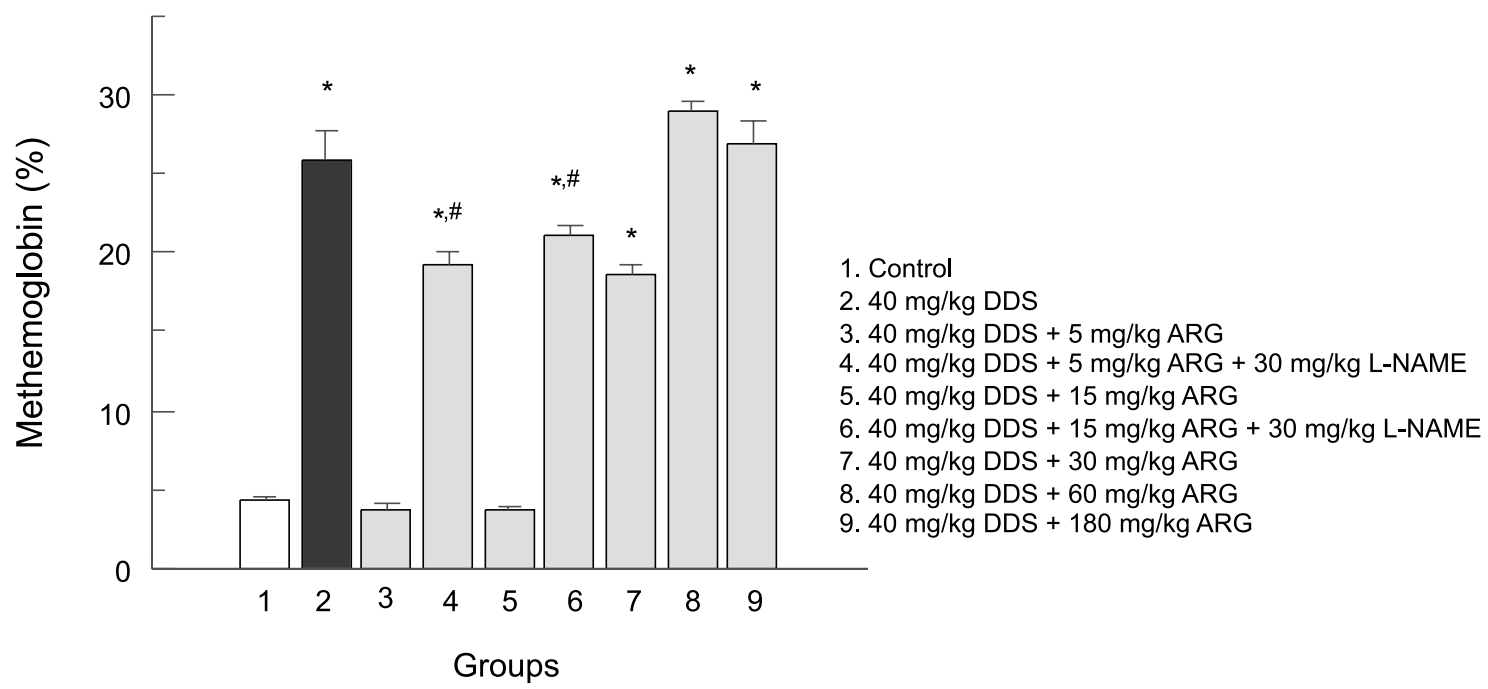

FIGURE 2 - Effect of multiple dose L-arginine (ARG) on methemoglobin level (\%). Animals were treated with saline or ARG at 5 , $15,30,60$ and $180 \mathrm{mg} / \mathrm{kg}$ doses (p.o., gavage) or simultaneous gavage of ARG at 5 and $15 \mathrm{mg} / \mathrm{kg}$ doses and $30 \mathrm{mg} / \mathrm{kg}$ L-NAME for five days. On the fifth day, rats were treated with $40 \mathrm{mg} / \mathrm{kg}$ DDS (i.p.) 2 hours after ARG administration. Data expressed as means \pm standard deviation. ${ }^{*} \mathrm{p}<0.001$ compared to the Control group; ${ }^{*} \mathrm{p}<0.001$ when groups treated with L-NAME are compared to the respective group without L-NAME.

$1.59 \pm 0.05 \%, 1.96 \pm 0.08 \%$ and $2.03 \pm 0.37 \%$ of methemoglobin, respectively (data expressed as means \pm standard deviation). These results showed that ARG alone did not produce methemoglobin.

Administration of $40 \mathrm{mg} / \mathrm{kg}$ DDS (i.p.) resulted in methemoglobin levels of $17.18 \pm 1.71 \%$ (Figure 1). The dose of $40 \mathrm{mg} / \mathrm{kg}$ (i.p.) of DDS was known to produce methemoglobinemia in rats based on previous studies by our group (Malfara et al., 2002; De Moraes et al., 2008; Bergamaschi et al., 2011). When ARG was administered in a single dose two hours prior to DDS $(40 \mathrm{mg} / \mathrm{kg})$ it failed to reduce DDS-induced methemoglobinemia (Figure 1).

ARG was also administered at doses 5, 15, 30, 60 and $180 \mathrm{mg} / \mathrm{kg}$ (po), in multiple dose regimens. Methemoglobin levels of groups treated with ARG only, in a multiple drug regimen, did not produce significant levels of methemoglobin $(1.88 \pm 0.68 \% ; 2.00 \pm 0.13 \% ; 2.56 \pm$ $0.44 \% ; 2.43 \pm 0.43 \%$ and $1.75 \pm 0.76 \%$, respectively), as observed for a single dose regimen. Animals treated with 5 or $15 \mathrm{mg} / \mathrm{kg}$ ARG for 5 days prior to $40 \mathrm{mg} / \mathrm{kg}$ DDS administration showed a reduction in DDS-induced methemoglobinemia, with methemoglobin levels similar to the control group. However, higher doses of ARG (30, 60 and $180 \mathrm{mg} / \mathrm{kg}$ ) in the multiple dose regimens did not inhibit methemoglobin formation (Figure 2).

The effect of L-NAME, a NOS inhibitor, was evaluated in order to understand the mechanisms related to the reduction of DDS-induced methemoglobinemia by ARG. L-NAME inhibited the reduction in DDS-induced methe- moglobinemia promoted by ARG, leading to MetHb levels comparable to DDS administration alone (Figure 2).

\section{DISCUSSION}

The concentration of methemoglobin in erythrocytes is regulated by three systems: nicotinamide adenine dinucleotide (NADH), nicotinamide adenine dinucleotide phosphate (NADPH) and glutathione systems. Methemoglobin is converted to hemoglobin by the NADH system when sufficient NADH-methemoglobin reductase is available; it contributes to $95 \%$ of methemoglobin reduction to hemoglobin. The NADPH system reduces methemoglobin to hemoglobin through the enzyme NADPH-methemoglobin reductase and contributes to $5 \%$ of methemoglobin reduction. Finally, the conversion of reduced glutathione to glutathione influences methemoglobin levels by reducing oxidizing agents (Evelo et al., 1998; Ward, McCarthy, 1998; Umbreit, 2007).

The standard treatment for methemoglobinemia includes infusion with methylene blue, whose action depends on the availability of NADPH within the erythrocytes. This therapy requires glucose-6-phosphate dehydrogenase (G6PD) optimal activity to produce sufficient amounts of NADPH. In G6PD-deficient subjects, methylene blue therapy has been associated with hemolysis and methemoglobinemia (Rehman, 2001). Several other substances have been investigated as alternatives to methylene blue therapy. These have included ascorbic acid (Dötsch 
et al., 1998), cimetidine (Coleman et al., 1990; Malfará et al., 2002), riboflavin (Dötsch et al., 2000), $\alpha$-lipoic acid (Coleman, Taylor, 2003), sodium thiosulfate (Matteucci et al., 2003), ethyl pyruvate (Jo et al., 2008) and $\mathrm{N}$-acetylcysteine (Wright et al., 1996; Wright et al., 1998; Dötsch et al., 2000; Tanen et al., 2000; De Moraes et al., 2008). $N$-acetylcysteine, a precursor of glutathione, used in combination with DDS in rats, has shown increased methemoglobin levels in these animals compared to rats treated with DDS alone. Some authors have suggested that glutathione can regenerate DDS-NOH from dapsone nitroso derivatives thus resulting in higher methemoglobin levels (De Moraes et al., 2008).

Considering the potency of ARG and $\mathrm{NO}$ as antioxidant agents, it was proposed that the co-administration of ARG and DDS might reduce the methemoglobin levels associated to DDS use. The cationic amino acid ARG is the precursor for NO biosynthesis mediated by NO synthase. Three isoforms of NO synthase (NOS) occur in a number of tissues: neuronal NOS (nNOS); inducible NOS (iNOS) located in glia cells, and endothelial NOS (eNOS) located in endothelial cells (Palmer et al., 1987; Thomas et al., 2008). The iNOS can form much larger amounts of NO compared with other isoforms. In many cells and pathological conditions the supply of extracellular ARG is rate-limiting for NO production (Brunini et al., 2007; Thomas et al., 2008).

In the present study, L-NAME administration suppressed the reduction in DDS-induced methemoglobinemia mediated by $5 \mathrm{mg} / \mathrm{kg}$ and $15 \mathrm{mg} / \mathrm{kg} \mathrm{ARG}$ in multiple dose regimens. Considering that L-NAME is a non-specific NOS inhibitor, our data suggest that the ARG effect on methemoglobin is mediated by NO. NO is considered a potent antioxidant agent in vitro and in vivo. Its antioxidant activity has been proven by suppressing iron-induced generation of hydroxyl radicals $(\mathrm{OH})$ via the Fenton reaction, interrupting lipid peroxidation chain reaction, increasing the glutathione antioxidant potency and inhibiting cysteine proteases (Chiueh, 1999). On the other hand, increased methemoglobin levels are a known toxic effect of inhaled NO therapy, commonly used for hypoxic neonates. NO can combine with hemoglobin to produce nitrosylhemoglobin and thus form methemoglobin by oxidation (Weinberger et al., 2001; Hamon et al., 2010). Based on our observations, we can hypothesize that lower doses of ARG were beneficial to decrease methemoglobin levels because of the antioxidant properties of NO. However, higher doses of ARG do not decrease metHb levels because the antioxidant properties of $\mathrm{NO}$ are combined to its methemoglobinizant effect.

Excess ARG supplementation is also related with the production of $N^{G}, N^{G}$-dimethyl-L-arginine (ADMA) which is a NOS inhibitor (Masuda et al. 2002). This metabolite can convert NO to a superoxide generator (Thomas et al., 2008). This may explain why NO is beneficial to DDSinduced methemoglobinemia at low ARG concentrations yet deleterious when excess ARG supplementation is administered to rats in multiple dose regimens.

NO also produces inhibitory effects in cytochrome P450 mediated drug metabolism. It is known that NO forms complexes with the catalytic center of P450 enzymes which results in a decrease in enzymatic activities of rat microsomes (Khatsenko et al. 1993). The inhibitory effects of $\mathrm{NO}$ are rapid, concentration-dependent and mainly in CYP $2 \mathrm{C} 11>2 \mathrm{~B} 1 / 2>2 \mathrm{E} 1=3 \mathrm{~A} 2>1 \mathrm{~A} 1 / 2$ (Vuppugalla, Mehvar 2004a, 2004b). If NO had inhibited DDS oxidative metabolism, animals treated with higher ARG concentration would present lower metHb levels. However, our results showed that the reduction in MetHb levels by ARG is observed only when animals are treated with multiple doses of 5 and $15 \mathrm{mg} / \mathrm{kg}$ ARG. Thus, CYP inhibition by NO does not seem to explain the reduction in MetHb levels.

In conclusion, ARG reduces DDS-induced methemoglobinemia in rats when low doses ( 5 and $15 \mathrm{mg} / \mathrm{kg}$ ) are administered as a multiple dose regimen. The effect can be blocked by the simultaneous administration of L-NAME (a NOS inhibitor). Thus, we can conclude that ARG supplementation can be an effective reducing agent for chronic treatment of DDS-induced methemoglobinemia and that its effect is mediated by NO.

\section{ACKNOWLEDGMENTS}

This work was supported by CAPES (Coordenação de Aperfeiçoamento de Pessoal de Nível Superior). The authors gratefully thank FURP (Fundação para o Remédio Popular) for providing dapsone and Prof. Dr. Lusiane Maria Bendhack for providing L-NAME.

\section{REFERENCES}

BERGAMASCHI, M.M.; ALCANTARA, G.K.; VALERIO, D.A.; QUEIROZ, R.H. Curcumin could prevent methemoglobinemia induced by dapsone in rats. Food Chem. Toxicol., v.49, n.7, p.1638-1641, 2011.

BRUNINI, T.M.; MOSS, M.B.; SIQUEIRA, M.A.; SANTOS, S.F.; LUGON J.R.; MENDES-RIBEIRO, A.C. Nitric oxide, malnutrition and chronic renal failure. Cardiovasc. Hematol. Agents Med. Chem., v.5, n.2, p.155-161, 2007. 
CASTRO, M. Treatment and prophylaxis of Pneumocystis carinii pneumonia. Semin. Respir. Infect., v.13, n.4, p.296303, 1998.

CHIUEH, C.C. Neuroprotective properties of nitric oxide. Ann. N.Y. Acad. Sci., v.890, p.301-311, 1999.

COLEMAN, M.D.; HOLDEN, L.J. The methaemoglobin forming and GSH depleting effects of dapsone and monoacetyl dapsone hydroxylamines in human diabetic and non-diabetic erythrocytes in vitro. Environ. Toxicol. Pharmacol., v.17, n.1, p.55-59, 2004.

COLEMAN, M.D.; PAHAL, K.K.; GARDINER, J.M. The effect of acetylation and deacetylation on the disposition of dapsone and monoacetyl dapsone hydroxylamines in human erythrocytes in-vitro. J. Pharm. Pharmacol., v.48, n.4, p.401-406, 1996.

COLEMAN, M.D.; SCOTT, A.K.; BRECKENRIDGE, A.M.; PARK, B.K. The use of cimetidine as a selective inhibitor of dapsone N-hydroxylation in man. Br. J. Clin. Pharmacol., v.30, n.5, p.761-767, 1990.

COLEMAN, M.D.; TAYLOR, C.T. Effects of dihydrolipoic acid (DHLA), $\alpha$-lipoic acid, $\mathrm{N}$-acetyl cysteine and ascorbate on xenobiotic-mediated methaemoglobin formation in human erythrocytes in vitro. Environ. Toxicol. Pharmacol., v.14, n.3, p.121-127, 2003.

COLEMAN, M.D. Dapsone toxicity: some current perspectives. Gen. Pharmacol., v.26, n.7, p.1461-1467, 1995.

DE MORAES, N.V.; MELLO, M.H.; SOUZA, A.M.; SAMPAIO, S.V.; QUEIROZ, R.H.C. Potentiation of dapsone induced methemoglobinemia by $\mathrm{N}$-acetylcysteine in rats. Rev. Bras. Cienc. Farm., v.44, n.1, p.97-104, 2008.

DÖTSCH, J.; DEMIRAKÇA, S.; CRYER, A.; HÄNZE, J.; KÜHL, P.G.; RASCHER, W. Reduction of NO-induced methemoglobinemia requires extremely high doses of ascorbic acid in vitro. Intensive Care Med., v.24, n.6, p.612$615,1998$.

DÖTSCH, J.; DEMIRAKÇA, S.; KRATZ, M.; REPP, R.; KNERR, I.; RASCHER, W. Comparison of methylene blue, riboflavin and $\mathrm{N}$-acetylcysteine for the reduction of nitric oxide-induced methemoglobinemia. Crit. Care Med., v.28, n.4, p.958-961, 2000.
EVELO, C.T.; SPOOREN, A.A.; BISSCHOPS, R.A.; BAARS, L.G.; NEIS, J.M. Two mechanisms for toxic effects of hydroxylamines in human erythrocytes: involvement of free radicals and risk of potentiation. Blood Cells Mol. Dis., v.24, n.3, p.280-295, 1998.

EVELYN, K.A.; MALLOY, H.T. Microdetermination of oxyhemoglobin, methemoglobin and sulfhemoglobin in a single sample of blood. J. Bio. Chem., v.126, p.655-662, 1938

FLEMING, C.M.; BRANCH, R.A.; WILKINSON, G.R.; GUENGERICH, F.P. Human liver microsomal N-hydroxylation of dapsone by cytochrome P-4503A4. Mol. Pharmacol., v.41, n.5, p.975-980, 1992.

GANESAN, S.; SAHU, R.; WALKER, L.A.; TEKWANI, B.L. Cytochrome P450-dependent toxicity of dapsone in human erythrocytes. J. Appl. Toxicol., v.30, n.3, p.271-275, 2010.

GILL, H.J.; TINGLE, M.D.; PARK, B.K. N-hydroxylation of dapsone by multiple enzymes of cytochrome P450: implications for inhibition of haematoxicity. Br. J. Clin. Pharmacol., v.40, n.6, p.531-538, 1995.

HAMON, I.; GAUTHIER-MOULINIER, H.; GRELETDESSIOUX, E.; STORME, L.; FRESSON, J.; HASCOET, J.M. Methaemoglobinemia risk factors with inhaled nitric oxide therapy in newborn infants. Acta Paediatr., v.99, n.10, p.1467-1473, 2010.

HARRISON JR., J.H.; JOLLOW, D.J. Role of aniline metabolites in aniline-induced hemolytic anemia. $J$. Pharmacol. Exp. Ther, v.238, n.3, p.1045-1054, 1986.

JO, Y.H.; KWON, W.Y.; LEE, J.H.; KIM, K.; SHIN, S.D.; KANG, Y.J.; SUH, G.J. The effect of ethyl pyruvate on dapsone-induced methemoglobinemia in rats. Clin. Toxicol. (Phila)., v.46, n.9, p.811-814, 2008.

KALUARACHCHI, S.I.; FERNANDOPULLE, B.M.; GUNAWARDANE, B.P. Hepatic and haematological adverse reactions associated with the use of multidrug therapy in leprosy - a five year retrospective study. Indian J. Lepr, v.73, n.2, p.121-129, 2001.

KATOCH, V.M. Advances in the diagnosis and treatment of leprosy. Expert Rev. Mol. Med., v.4, n.15, p.1-14, 2002. 
KHATSENKO, O.G.; GROSS, S.S.; RIFKIND, A.B.; VANE, J.R. Nitric oxide is a mediator of the decrease in cytochrome P450-dependent metabolism caused by immunostimulants. Proc. Natl. Acad. Sci. USA, v.90, n.23, p.11147-11151, 1993.

MALFARÁ, W.R.; PEREIRA, C.P.; SANTOS, A.C.; QUEIROZ, R.H. Effects of H(2)-receptor antagonists on dapsoneinduced methaemoglobinaemia in rats. Pharmacol. Res., v.45, n.4, p.269-273, 2002.

MASUDA, H.; TSUJII, T.; OKUNO, T.; KIHARA, K.; GOTO, M.; AZUMA, H. Accumulated endogenous NOS inhibitors, decreased NOS activity, and impaired cavernosal relaxation with ischemia. Am. J. Physiol. Regul. Integr. Comp. Physiol., v.282, n.6, p.R1730-1738, 2002.

MATTEUCCI, M.J.; REED, W.J.; TANEN, D.A. Sodium thiosulfate fails to reduce nitrite-induced methemoglobinemia in vitro. Acad. Emerg. Med., v.10, n.4, p.299-302, 2003.

MILLS, J.; LEOUNG, G.; MEDINA, I.; HOPEWELL, P.C.; HUGHES, W.T.; WOFSY, C. Dapsone treatment of Pneumocystis carinii pneumonia in the acquired immunodeficiency syndrome. Antimicrob. Agents Chemother, v.32, n.7, p.1057-1060, 1988.

MITRA, A.K.; THUMMEL, K.E.; KALHORN, T.F.; KHARASCH, E.D.; UNADKAT, J.D.; SLATTERY, J.T. Metabolism of dapsone to its hydroxylamine by CYP2E1 in vitro and in vivo. Clin. Pharmacol. Ther, , v.58, n.5, p.556-566, 1995.

NYUNT, M.M.; PLOWE, C.V. Pharmacologic advances in the global control and treatment of malaria: combination therapy and resistance. Clin. Pharmacol. Ther, v.82, n.5, p.601-605, 2007.

PALMER, R.M.; FERRIGE, A.G.; MONCADA, S. Nitric oxide release accounts for the biological activity of endotheliumderived relaxing factor. Nature, v.327, p.524-526, 1987.

POWELL, R.D.; DEGOWIN, R.L.; EPPES, R.B.; MCNAMARA, J.V.; CARSON, P.E. The antimalarial and hemolytic properties of 4,4-diaminodiphenyl sulfone (DDS). Int. J. Lepr. Other Mycobact. Dis., v.35, n.4, p.590604, 1967.
PRUSSICK, R.; ALI, M.A.; ROSENTHAL, D.; GUYATT, $\mathrm{G}$. The protective effect of vitamin $\mathrm{E}$ on the hemolysis associated with dapsone treatment in patients with dermatitis herpetiformis. Arch. Dermatol., v.128, n.2, p.210-213, 1992.

REHMAN, H.U. Methemoglobinemia. West J. Med., v.175, n.3, p.193-196, 2001.

TANEN, D.A.; LO VECCHIO, F.; CURRY, S.C. Failure of intravenous $\mathrm{N}$-acetylcysteine to reduce methemoglobin produced by sodium nitrite in human volunteers: a randomized controlled trial. Ann. Emerg. Med., v.35, n.4, p.369-373, 2000.

THOMAS, D.D.; RIDNOUR, L.A.; ISENBERG, J.S.; FLORES-SANTANA, W.; SWITZER, C.H.; DONZELLI, S.; HUSSAIN, P.; VECOLI, C.; PAOLOCCI, N.; AMBS, S.; COLTON, C.A.; HARRIS, C.C.; ROBERTS, D.D.; WINK, D.A. The chemical biology of nitric oxide: implications in cellular signaling. Free Radic. Biol. Med., v.45, n.1, p.18$31,2008$.

TINGLE, M.D.; COLEMAN, M.D.; PARK, B.K. An investigation of the role of metabolism in dapsone-induced methaemoglobinemia using a two compartment in vitro test system. Br. J. Clin. Pharmacol., v.30, n.6, p.829-838, 1990.

TINGLE, M.D.; MAHMUD, R.; MAGGS, J.L.; PIRMOHAMED, M.; PARK, B.K. Comparison of the metabolism and toxicity of dapsone in rat, mouse and man. J. Pharmacol. Exp. Ther, v.283, n.2, p.817-823, 1997.

TOBIN-D’ANGELO, M.J.; HOTEIT, M.A.; BROWN, K.V.; RAY, S.M.; KING M.D. Dapsone-induced hypersensitivity pneumonitis mimicking Pneumocystis carinii pneumonia in a patient with AIDS. Am. J. Med. Sci., v.327, n.3, p.163$165,2004$.

UMBREIT, J. Methemoglobin-it's not just blue: a concise review. Am. J. Hematol., v.82, n.2, p.134-144, 2007.

VAGE, C.; SAAB, N.; WOSTER, P.M.; SVENSSON, C.K. Dapsone-induced hematologic toxicity: comparison of the methemoglobin-forming ability of hydroxylamine metabolites of dapsone in rat and human blood. Toxicol. Appl. Pharmacol., v.129, n.2, p.309-316, 1994. 
VAGE, C.; SVENSSON, C.K. Evidence that the biotransformation of dapsone and monoacetyldapsone to their respective hydroxylamine metabolites in rat liver microsomes is mediated by cytochrome $\mathrm{P} 4502 \mathrm{C} 6 / 2 \mathrm{C} 11$ and 3A1. Drug Metab. Dipos., v.22, n.4, p.572-577, 1994.

VUPPUGALLA, R.; MEHVAR, R. Hepatic disposition and effects of nitric oxide donors: rapid and concentrationdependent reduction in the cytochrome $\mathrm{P} 450$-mediated drug metabolism in isolated perfused rat livers. J. Pharmacol. Exp. Ther., v.310, n.2, p.718-727, 2004.

VUPPUGALLA, R.; MEHVAR, R. Short-term inhibitory effects of nitric oxide on cytochrome P450-mediated drug metabolism: time dependency and reversibility profiles in isolated perfused rat livers. Drug Metab. Dispos., v.32, n.12, p.1446-1454, 2004

WALKER, S.L.; LOCKWOOD, D.N. Leprosy. Clin. Dermatol., v.25, n.2, p.165-172, 2007.

WARD, K.E.; MCCARTHY, M.W. Dapsone-induced methemoglobinemia. Ann. Pharmacother, v.32, n.5, p.549553, 1998.
WEINBERGER, B.; LASKIN, D.L.; HECK, D.E.; LASKIN, J.D. The toxicology of inhaled nitric oxide. Toxicol. Sci., v.59, n.1, p.5-16, 2001.

WOOD, K.C.; HSU, L.L.; GLADWIN, M.T. Sickle cell disease vasculopathy: a state of nitric oxide resistance. Free Radic. Biol. Med., v.44, n.8, p.1506-1528, 2008.

WRIGHT, R.O.; MAGNANI, B.; SHANNON, M.W.; WOOLF, A.D. $\mathrm{N}$-acetylcysteine reduces methemoglobin in vitro. Ann. Emerg. Med., v.28, n.5, p.499-503, 1996.

WRIGHT, R.O.; WOOLF, A.D.; SHANNON, M.W.; MAGNANI, B. N-acetylcysteine reduces methemoglobin in an in-vitro model of glucose-6-phosphate dehydrogenase deficiency. Acad. Emerg. Med., v.5, n.3, p.225-229, 1998.

Received for publication on $13^{\text {th }}$ April 2011 Accepted for publication on $06^{\text {th }}$ December 2011 